\title{
Defense Spending and Economic Growth in China, India, Nepal and Pakistan: Evidence from Cointegrated Panel Analysis
}

\author{
Rudra Prakash Pradhan \\ Vinod Gupta School of Management, Indian Institute of Technology, Kharagpur, India \\ E-mail: rudrap@vgsom.iitkgp.ernet.in
}

\begin{abstract}
The study investigates the nexus between defense spending and economic growth in China, India, Nepal and Pakistan. The empirical analysis is based on integration and cointegration properties of data over the period 1988-2007. The long run relationship between defense spending, economic growth and public debt are identified in a cointegration framework. The paper finds bidirectional causality between economic growth and public debt in China and India; unidirectional causality from defense spending to economic growth in China and Nepal, unidirectional causality from public debt to defense spending in India, and unidirectional causality from economic growth to public debt in Pakistan. The panel Granger causality test, however, confirms the presence of bidirectional causality between public debt and economic growth. The cointegration test at the end suggests that defense spending of a particular country can affect the defense spending of other country.
\end{abstract}

Keywords: Defense spending, Economic growth, Panel cointegration

\section{Introduction}

India's dispute with China, Nepal and Pakistan are well known and has been a standing issue in South Asia. Historically, the disputes are basically on the boundary issue. However in the recent times, there are various other problems that give raise to conflict among these countries. These are militancy problems, insurgents, existence of various ethnics groups in the region, lack of understanding among the people, lack of accountability of the officials, poor governance, lack of capital and so forth. The above issues lead to military burden in the respective countries and hence, affecting their defense spending and economic growth. It is expected that these countries' defense expenditure are somewhat cointegrated. Therefore, the study aims to investigate, whether there is any long run relationship between these countries' defense expenditure. It also explores the long run relation between defense spending and economic growth in the four countries, namely, China, India, Nepal and Pakistan.

The long run relationship between defense spending and economic growth is not something new. It is rather debated in the development literature since the seminal work of Benoit $(1973,1978)$, who found the positive association between the two. The debate is, however, due to the positive (Brumm, 1997; Knight et al., 1996; Melman, 1988; Looney, 1986) and negative (Klein, 2004; Deger, 1986; Faini et al., 1984; Lim, 1983; Deger and Sen, 1983; Deger and Smith, 1983) spillovers between defense spending and economic growth and the inconclusiveness of the direction of causality. There are two ways we can see the relationship between defense spending and economic growth: first, regression approach, where the direction of causality does not serious matter and second, time series approach, where the direction of causality does serious matter. A number of research papers have been concerned with the empirical relationship between defense spending and economic growth in different countries over different periods (see Hirnissa et al., 2008; Yildirim and Ocal, 2006; Yildirim et al., 2005; Reitschuler and Loening, 2005; Yildirim et al., 2005; Halicioglu, 2004; Kollias et al., 2004; Ocal, 2003; Shieh et al., 2002; Atesoglu, 2002; Dakurah et al., 2001; Dunne et al., 2001; Stroup and Heckelman, 2001; Frederiksen and McNab, 2001; Kollias and Makrydakis, 2000; Dunne and Vougas, 1999; Georgiou et al., 1996; Nadir, 1993; Chowdhury, 1991; Frederiksen, 1991; Alexander, 1990; Frederiksen and LaCivita, 1987; Looney and Frederiksen, 1986; Joerding, 1986). The empirical findings are, nevertheless, very contradictory. Some are getting support of the positive association between defense spending and economic growth, while others do not. There are number of concerns on the conflict between defense spending and economic growth. These include variable reorganization, different estimation techniques, small sample size and so forth.

The present study focuses the time series approach on the nexus between defense spending and economic growth. The empirical research addresses three problems: first, whether defense spending of a particular country responds to defense spending of other countries; second, whether defense spending increases economic growth or whether enhance in economic growth actually determines defense spending; and third, whether public debt has a considerable role on the nexus between defense spending and economic growth. The investigation of these objectives could support various policy implications in the process of economic development. The remaining of the 
paper is organized as follows: section 2 describes theoretical background and econometric setting; section 3 presents the empirical results; and section 4 provides concluding remarks.

\section{Theoretical Background and Econometric Setting}

The issue on the empirical relationship between defense spending and economic growth is very important in Asia, particularly for the policy view point. Historically, there has been active discussion regarding the defense spending in Asia in order to restore better stability in the region. A pre-requisite for restoring peace in the region is to spend more in the defense sector. This is because defense spending can provide lots of positives in the economic development, both directly and indirectly. Some of these positives are as follows:

- Defense spending promotes economic growth, if some of the expenditure is used for the creation of socio-economic infrastructure like roads, bridges, airports, hospitals and so forth.

- Defense spending leads to formation of human capital, if the part of defense spending is used for education, training, discipline and so forth.

- Defense spending can provide protection to the citizens, where internal and external security promotes market exchange.

- Defense spending can improve productivity and generate welfare, if the part of spending is used for revamping the economy during crisis times like earthquake, floods, terrorist attacks and so forth.

- Defense spending provides direct technology benefits and spin- offs, where the spin- offs applied to civil sector can promote economic growth.

- In the period of unemployment, defense spending certainly provides stimulate effect to economic growth.

Defense spending, in some instances, can affect the economic development negatively, if it can crowd out the civilian expenditure. So proper understanding on the relationship between defense spending and economic growth is very urgent requirement in the region. The exploration will certainly give better policy implications in the particular countries.

The investigation on the nexus between defense spending and economic growth is undertaken by cointegration and causality test at the individual country level and panel of four countries. Let GDP $_{\text {it }}$ denote economic growth in country $i$ and year $t(i=1,2, \ldots . . n ; t=1,2, \ldots T), G E D_{i t}$ be the defense spending in country $i$ at time period $t, \operatorname{PUD}_{\text {it }}$ denotes the public debt in country $\mathrm{i}$ at the time period $t$. Then we design the following panel data model to investigate the nexus between defense spending and economic growth.

$$
\begin{aligned}
& G D P_{i t}=\alpha_{0 i}+\alpha_{1 i} G E D_{i t}+\alpha_{2 i} P U D_{i t}+\varepsilon_{i t} \\
& G E D_{i t}=\alpha_{0 i}+\alpha_{1 i} G D P_{i t}+\alpha_{2 i} P U D_{i t}+\varepsilon_{i t} \\
& P U D_{i t}=\alpha_{0 i}+\alpha_{1 i} G D P_{i t}+\alpha_{2 i} G E D_{i t}+\varepsilon_{i t}
\end{aligned}
$$

However, the prime requirement of this modelling is to check the stationarity of time series variables. If the stationarity is violated, this could be lead to spurious results. There are various tests available to check the stationarity at the individual data series as well as panel data series. However, the Phillips and Peron (PP) unit root test has been applied at the individual country level and LLC and IPS have been applied at the panel level. The PP test requires estimation of the following equation (Phillips and Perron, 1988):

$$
\mathbf{Y}_{t}=\alpha_{t}+\sum_{i=1}^{T} Y_{t-T}+\varepsilon_{t}
$$

Where $\mathrm{X}$ is the variable of choice and the PP test-statistic under the null hypothesis is

$$
Z\left(t_{\mu}\right)=\left\langle S_{u} \mid S_{t k}\right\rangle t_{\mu}-\frac{1}{2}\left(S_{t k}^{2}-S_{u}^{2}\right)\left[S_{t k}\left\{T^{2} \sum_{t=2}^{T}\left(Y_{t}-Y_{t-k}\right)^{2}\right\}^{\frac{1}{2}}\right]^{-1}
$$

Let "d" is defined as the number of times that a variable needs to be differenced in order to attain stationary. In such a case, variable is said to be integrated of order "d" and denoted by I (d). If the variable is stationary at the level data, it is integrated of order zero [I (0)]. Similarly if the variable is stationary at the first difference, it is integrated of order one [I (I)] and so on. But the limitation of this PP technique is that it has a problem of low power in rejecting the null hypothesis of stationarity, particularly for small size of data. On the contrary, panel unit root test has been applied at the group level. It basically deals with two statistics such as LLC and IPS. The LLC test (Levin et al., 2002) imposes homogeneity on the autoregressive coefficient, which indicates the presence or absence of a unit root 
whereas the intercept and trend can vary across individual series. The model only allows for heterogeneity in the intercept and is given by

$$
\Delta Y_{i t}=\alpha_{i}+\gamma Y_{i t-i}+\sum_{p=1}^{n_{i}} \beta_{j} \Delta Y_{i t-p}+\varepsilon_{i t}
$$

Where $Y_{\text {it }}$ is a series for panel member (country) $i(i=1,2, . . N)$ over the period $t(t=1,2, \ldots T), p_{i}$ is the number of lags in the ADF regression and the error term $\varepsilon_{i, t}$ are assumed to be IID $\left(0, \sigma^{2}\right)$ and to be independent across the units of the sample. The model allows for fixed effects, unit specific time trends and common time effects. The coefficient of the lagged dependent variable is restricted to be homogenous across all units of the panel. Hence, the null hypothesis of non-stationary is as follows:

The fixed effect model in equation (6) is based on the usual t-statistics.

$$
t_{\gamma}=\frac{\hat{\gamma}}{\operatorname{se}(\hat{\gamma})}
$$

The above LIC statistics assumes homogeneity in the dynamics of the autoregressive coefficients for all panel numbers, while IPS assumes for heterogeneity in these dynamics. Therefore, it is otherwise called as "heterogeneous panel unit root tests". The IPS specification is obtained from the following model.

$$
\Delta Y_{i t}=\alpha_{i}+\gamma_{i} Y_{i t-i}+\sum_{p=1}^{n} \beta_{i j} \Delta Y_{i t-p}+\varepsilon_{i t}
$$

Where series $y_{i, t}(i=1,2, \ldots, N ; t=1,2, \ldots, T)$ is the series for panel member (country) $i$ over period, $p_{i}$ is the number of lags in the ADF regression and the error terms $\varepsilon_{i, t}$ are assumed to be IID $\left(0, \sigma_{i}^{2}\right)$ for all $i$ and t. Both $\gamma_{i}$ and the lag order $\beta$ in equation (6) are allowed to vary across sections (countries). The IPS offers the assumption of homogeneity of the coefficient of the lagged dependent variable. They test the null hypothesis that each series in the panel has a unit root for all cross-section units against the alternative that at least one of the series is stationary. The alternative hypothesis simply implies that some or all of the individual series are stationary.

The IPS is represented by two test statistics: t-bar and LM-bar tests. The IPS t-bar statistics is calculated using the average of the individual Dickey-Fuller $\tau$ statistics.

$$
\bar{t}=\frac{1}{N} \sum_{i=1}^{N} \tau_{i} \text { and } \tau_{i}=\frac{\widehat{\gamma}_{i}}{\operatorname{se} e\left(\widehat{\gamma}_{i}\right)}
$$

Where the assumption is that the cross sections are independent. The IPS proposes the use of the standardized t-bar statistic as shown below.

$$
\bar{Z}=\frac{\sqrt{N}(\bar{t}-E(\bar{t}))}{\sqrt{\operatorname{Var}(\bar{t})}}
$$

The term $E(\bar{t})$ and $\operatorname{Var}(\bar{t})$ are the mean and variance of $\tau$ statistic. They are generated by simulations and are tabulated in IPS (Im et al., 2003).

When the series becomes stationary, the next step is to know the presence of long run relationship among the set of the integrated variables. It is also applied at the individual and panel level.

The Johansen (1988) maximum likelihood (ML) test is applied at the individual level. The technique follows with estimation of the below equation.

$$
\Delta X_{t}=A_{0}+\prod X_{t-p}+\sum_{i=1}^{p-1} A_{i} \Delta X_{t-i}+\varepsilon_{t}
$$

Where, vector $\Delta X_{t}$ and $\Delta X_{t-1}$ are expected to be I (1) representation. The long run equilibrium relationship among $X_{t}$ is determined by the rank of $\Pi$ (say r) is zero. If $0<\mathrm{r}<\mathrm{n}$, then there are $\mathrm{n} X \mathrm{r}$ matrices of $\alpha$ and $\beta$ such that

$$
\Pi=\alpha \beta^{\prime}
$$

Where, both $\alpha$ and $\beta$ are ( $\mathrm{n} \times \mathrm{r}$ ) matrices. The cointegrating vectors $\beta$ have the property that $\beta^{\prime} X_{t}$ is stationary [I (0)] even though $X_{t}$ is non-stationary [I (1)]. Johansen likelihood ratio test looks for two statistics: trace statistics and maximum eigen value.

The likelihood ratio test statistic for the null hypothesis that there are at most $r$ cointegrating vectors is the trace test and is computed as: 


$$
\text { Trace }=-T \sum_{i=r+1}^{n} \log \left(1-\hat{\lambda}_{i}\right)
$$

Where $\hat{\lambda}_{r+1}, \ldots . \hat{\lambda}_{n}$ are (n-r) smallest estimated eigen values.

The likelihood ratio test statistic for the null hypothesis of $r$ cointegrating vectors against the alternative of $r+1$ cointegrating vectors is the maximum eigen value test and is given by

$$
\lambda_{\max }=-T \log \left(1-\hat{\lambda}_{r+1}\right)
$$

Here, the null hypothesis of $r$ cointegrating vectors is tested against the alternative hypothesis of $r+1$ cointegrating vectors. Johansen's procedure is very useful in conducting individual cointegration tests, but does not deal with cointegration in the panel setting. The Pedroni (2004) provides a technique that allows for using panel data. The Pedroni's panel cointegration test involves the estimation of following equation.

$$
\begin{aligned}
& Y_{i t}=\alpha_{i}+\sum_{j=1}^{m} \beta_{j i} Y_{j i t}+\varepsilon_{i t} \\
& \text { Where } \varepsilon_{i t}=\rho_{i} \varepsilon_{i(t-1)}+w_{i t}
\end{aligned}
$$

The tests for the null of no cointegration are based on testing whether the error process $\varepsilon_{\mathrm{it}}$ is stationary. The null hypothesis to be tested is $\rho_{\mathrm{i}}=1$. Pedroni test involves seven tests and grouped under two heads. The test statistics in the first group are averages of the cointegration time series test across cross-sections. The alternative hypothesis for those tests is $\rho_{i}=\rho<1$. The test statistic in the second group are based on averaging the individual estimated values of $\rho_{\mathrm{i}}$ for each cross section unit $\mathrm{i}$. The alternative hypothesis for those tests is that $\rho_{\mathrm{i}}<1$ for all $\mathrm{i}$.

The Johansen's VAR model and Pedroni's heterogeneous panel cointegration can indicate the presence of long run relationship between the two or more time series variables. But they cannot indicate the direction of causality. We also apply the causality test by individual series (Granger, 1988) and in the panel setting. For individual country specific test, we apply the following model.

$$
\begin{gathered}
(1-L) G D P_{t}=\alpha_{0}+\sum_{i=1}^{p} \alpha_{i}(1-L) G D P_{t-i}+\sum_{j=1}^{q} \beta_{j}(1-L) G E D_{t-j}+ \\
\sum_{k=1}^{r} \delta_{k}(1-L) P U D_{t-k}+\eta_{1} E C T_{-1}+\varepsilon_{t} \\
(1-L) G E D_{t}=\beta_{0}+\sum_{i=1}^{p} \beta_{i}(1-L) G E D_{t-i}+\sum_{j=1}^{q} \alpha_{j}(1-L) G D P_{t-j}+ \\
\sum_{k=1}^{r} \delta_{k}(1-L) P U D_{t-k}+\eta_{2} E C T_{-1}+\varepsilon_{t} \\
(1-L) P U D_{t}=\delta_{0}+\sum_{i=1}^{p} \delta_{i}(1-L) P U D_{t-i}+\sum_{j=1}^{q} \beta_{j}(1-L) G E D_{t-j}+ \\
\sum_{k=1}^{r} \alpha_{k}(1-L) G D P_{t-k}+\eta_{3} E C T_{-1}+\varepsilon_{t}
\end{gathered}
$$

Where GDP is economic growth, GED is government spending on defense and PUD is public debt. L is the lag operator and $\mathrm{ECT}_{-1}$ represents the error correction term lagged one period obtained from the cointegrating equation. The direction of causality can be detected here through three channels: the coefficients of the lagged independent variables, the coefficient of the error term and the coefficients of the error correction term and the lagged independent variables.

Coming to panel causality test, Holz- Eakin et al. (1988) model has been applied. The panel causality model is presented as follows.

$$
\begin{aligned}
& (1-L) G D P_{i t}=\alpha_{i G D P}+\sum_{p=1}^{m} \alpha_{11 i p}(1-L) G D P_{i t-p}+\sum_{p=1}^{n} \alpha_{12 i p}(1-L) G E D_{i t-p}+ \\
& \sum_{p=1}^{r} \alpha_{13 i p}(1-L) P U D_{i t-p}+\eta_{1 i} E C T_{i t-1}+\varepsilon_{i t}
\end{aligned}
$$




$$
\begin{aligned}
& (1-L) G E D_{i t}=\alpha_{i G E D}+\sum_{p=1}^{m} \alpha_{21 i p}(1-L) G E D_{i t-p}+\sum_{p=1}^{n} \alpha_{22 i p}(1-L) G D P_{i t-p}+ \\
& \sum_{p=1}^{r} \alpha_{23 i p}(1-L) P U D_{i t-p}+\eta_{2 i} E C T_{i t-1}+\varepsilon_{i t} \\
& (1-L) P U D_{i t}=\alpha_{i P U D}+\sum_{p=1}^{m} \alpha_{31 i p}(1-L) P U D_{i t-p}+\sum_{p=1}^{n} \alpha_{32 i p}(1-L) G E D_{i t-p}+ \\
& \sum_{p=1}^{r} \alpha_{33 i}(1-L) G D P_{i t-p}+\eta_{3 i} E C T_{i t-1}+\varepsilon_{i t}
\end{aligned}
$$

Where $\mathrm{p}$ is lag length and other notations are already defined. The optimal lag length has been selected here by using Akaike information criteria. The short run causality is tested by the significance of $\alpha_{\text {s, }}$, while the long run causality can be tested by looking at the significance of the coefficient of the error term. That means the change in the endogenous variable is caused not only by their lags, but also by the previous period's disequilibrium. The joint test indicates which variables bear the burden of short run adjustment to reestablish the long run equilibrium, following a shock to the system. If there is no causality in either direction, the neutrality hypothesis holds true. The details of the methodology adopted in this paper are summarized in Figure 1.

The empirical analysis is based on a panel of four South Asian countries, namely China, India, Nepal and Pakistan, over the period 1988-2007. The choice of countries is selected on the basis of India's conflict with neighboring countries. The span of data reflects the data availability of three variables, namely economic growth, defense spending and public debt. The GDP is used as a proxy to economic growth, while military expenditure is expressed as a percentage to GDP is used as a proxy to defense spending. The public debt is considered as a percentage to GDP. The data are obtained from World Development Indicators, World Bank and Stockholm International Peace Research Institute, Stockholm. The data are used in logarithmic form for the empirical investigation.

\section{Results and Discussion}

In the light of methodology presented in the above, the empirical results are discussed in this section. The analysis is based on the test of stationarity of the time series data, both at the individual level and panel level. For testing the stationarity of the individual time series, the Phillips and Perron unit root test is deployed. The estimated results are presented in Table 1. It indicates that all the time series variables that used in the study have unit roots in their levels but not in their first differences at conventional levels of statistical significance. This implies that these time series variables achieve stationarity after the first differencing. Hence, the variables are integrated of order one, i.e. 1 (1). Panel unit root tests, on the contrary, are expected to be much more powerful since they combine information from time series as well as cross-sectional data. The IPS, LLC, ADF and PP tests are conducted to check for the presence of unit root for all variables in both levels and first differences in the context of panel data. The results in Table 2 suggest that the time series variables are non-stationary in their levels but found stationary at their first differences. That means they are integrated of order one, i.e. I (1).

Having confirmed the existence of unit roots for all the data series, the next step is to check possibility of long run equilibrium relationship between them. The cointegration test is applied for the same at the individual level as well as panel level. The Johansen's maximum likelihood test has been applied for each country in the panel and Pedroni's panel cointegration test has been applied to the four countries in the panel. The Table 3 presents the Johansen's estimated results at the individual country level. The results rejected the null hypothesis of no-cointegration $(r=0)$ and one cointegration at the conventional levels of statistical significance for all sampled countries. The null hypothesis of two cointegrating vector is however not rejected in all these four cases. Hence, we can have strong evidence in favour of the hypothesis of one cointegrating vector. In other words for all countries we examine a unique cointegrating vector seems to be a reasonable hypothesis.

The power of individual Johansen's cointegration tests can be distorted when the span of the data is short. On the contrary, the panel cointegration could be very effective to provide suitable solutions to the existing problem. The present study have applied Pedroni's cointegration test to verify the same. The results of panel cointegration test are reported in Table 4. The results provide additional support to the existence of single cointegrating vectors. That means defense spending and economic growth share a long run equilibrium relationship in all the four Asian countries. This indicates that there is possibility of causality between defense spending and economic growth.

To examine the direction of causality between defense spending and economic growth, the Error Correction Model (ECM) is applied at the individual country level and the panel of four countries. The Table 5 presents the results of causality test, both at the individual level and panel level. The results for China imply an existence of short run 
bidirectional causality between economic growth and public debt. The results also authenticate an existence of unidirectional causality running from defense spending to economic growth. It further confirms that both public debt and defense spending adjust each other to restore long run equilibrium relationship when there is deviation from the equilibrium cointegrating relationship. In India, the results find an existence of short run bidirectional causality between economic growth and public debt. The results also indicate an existence of unidirectional causality running from public debt to defense spending. Additionally, it confirms that both public debt and defense spending can adjust each other to reinstate the long run equilibrium relationship between the two. For Nepal, the results confirm the presence of unidirectional short run causality running from defense spending to economic growth. In Pakistan, we find an existence of unidirectional short run causality running from economic growth to public debt. The panel Granger causality test finally confirms the presence of short run bidirectional causality between public debt and economic growth.

We have also examined whether defense spending of a particular country can affect the defense spending of other countries. The technique that we have used for the same is cointegration and the estimated empirical results are reported in Table 6. The results confirmed that there is no cointegration between defense spending of any two countries and three countries. However, we find two cointegrating vectors between defense spending of four Asian countries, namely China, India, Nepal and Pakistan. This implies that defense spending of a particular country can affect defense spending of other country.

\section{Conclusion}

The work explores the relationship between defense spending and economic growth in the four Asian countries, namely China, India, Nepal and Pakistan, over the period 1988- 2007. The empirical investigation has been carried out at the individual country level and a panel of four Asian countries. It also explores the cointegration between defense spending between the four Asian countries. The main findings of this study are summarized as follows:

1) Economic growth and defense spending are integrated of order one for the four Asian countries, namely China, India, Nepal and Pakistan, at the individual country level and at the group level.

2) Johansen's multivariate cointegration and Pedroni's panel cointegration test confirmed that there is evidence of cointegration. This suggests that long run relationship between defense spending and economic growth exists in the Asian four countries at the individual and panel level.

3) The error correction model confirms the bidirectional causality between economic growth and public debt in China and India. There is also an existence of unidirectional causality running from defense spending to economic growth in China and Nepal, unidirectional causality from public debt to defense spending in India, and unidirectional causality from economic growth to public debt in Pakistan. The panel Granger causality test finally confirms the presence of short run bidirectional causality between public debt and economic growth.

4) The cointegration test finally confirms that defense spending of four Asian countries is cointegrated, indicating the presence of long run equilibrium relationship between them. It suggests that defense spending of a particular country can affect the defense spending of other country.

\section{References}

Alexander, W. R. J. (1990).The Impact of Defense Spending on Economic Growth: A Multi- sectoral Approach to Defense Spending and Economic Growth with Evidence from Developed Economies. Defence Economics, 2, 39-55.

Atesoglu, H. S. (2002). Defense Spending Promotes Aggregate Output in the United States- Evidence from Cointegration Analysis. Defence and Peace Economics, 13, 55-60.

Benoit, E. (1973). Defense Spending and Economic Growth in Developing Countries. Lexington: Lexington Books.

Benoit, E. (1978). Growth and Defense Spending in Developing Countries. Economic Development and Cultural Change, 26, 271-280.

Brumm, H. (1997). Military Spending, Government Disarray and Economic Growth: A Cross Country Empirical Analysis. Journal of Macroeconomics, 19, 827-838.

Chowdhury, A. (1991). A Causal Analysis of Defense Spending and Economic Growth. Journal of Conflict Resolution, 35, 80-97.

Dakurah, A. H., Davies, S. P. \& Sampath, R. K. (2001). Defense Spending and Economic Growth in Developing Countries: A Causality Analysis. Journal of Policy Modelling, 23, 651-658.

Deger, S. (1986). Economic Development and Defense Expenditure. Economic Development and Cultural Change, $35,179-196$. 
Deger, S. \& Sen, S. (1983). Military Expenditure, Spin-off and Economic Development. Journal Development Economics, 13, 67-83.

Deger, S. \& Smith, R. (1983). Military Expenditure and Growth in LDCs. Journal Conflict Resolution, 27, 335-353.

Dunne, P. \& Vougas, D. (1999). Defense Spending and Economic Growth in South Africa. Journal of Conflict Resolution, 43, 523-542.

Dunne, P., Nikolaidou, E. \& Vougas, D. (2001). Defense Spending and Economic Growth: A Causal Analysis for Greece and Turkey. Defense and Peace Economics, 12, 1-26.

Fiani, R., Annez, P. \& Taylor, L. (1984). Defense Spending, Economic Structure and Growth: Evidence among Countries and Over Time. Economic Development and Cultural Change, 32, 487-498.

Frederiksen, P. C. (1991). Economic Growth and Defense Spending: Evidence on Causality for Selected Asian Countries. Journal of Philippine Development, 18, 131-147.

Frederiksen, P. C. \& LaCivita, C. J. (1987). Defense Spending and Economic Growth: Time Series Evidence on Causality for the Philippines, 1956-82. Journal of Philippine Development, 14, 354-360.

Frederiksen, P. C. \& McNab, R. (2001). The Relationship between Defense Spending and Economic Growth: A Granger Causality Analysis for Malaysia, 1961-1999. Journal of Strategic Studies on International Relations, 9, 63-71.

Georgiou, M. G., Kapopoulos, P. T. \& Lazaretou, S. (1996). Modelling Greek-Turkish Rivalry: An Empirical Investigation of Defense Spending Dynamics. Journal of Peace Research, 33, 229-239.

Granger, C. W. J. (1988). Some Recent Developments in a Concept of Causality, Journal of Econometrics, 39, 199-211.

Halicioglu, F. (2004). Defense Spending and Economic Growth in Turkey: An Empirical Application of New Macroeconomic Theory. Review of Middle East Economics and Finance, 2, 193-201.

Hirnissa, M. T., Habibullah, M. S. \& Baharom, A. H. (2008).Defense and Inequality: Evidence from Selected ASIAN Countries. MPRA Paper No. 11916, http://mpra.ub.uni-muenchen.de/11916.

Holtz- Eakin, D., Newey, W. \& Rosen, H. S. (1988). Estimating Vector Auto Regressions with Panel Data. Econometrica, 56: 1371-1395.

Im, K. S., Pesaran, M. H. \& Shin, Y. (2003). Testing for Unit Roots in Heterogeneous Panels, Journal of Econometrics, 115, 53-74.

Joerding, W. (1986). Economic Growth and Defense Spending. Journal of Development Economics, 21, 35-40.

Johansen, S. (1988). Statistical Analysis of Cointegrating Vectors, Journal of Economics Dynamic and Control, 12, 231-254.

Klein, T. (2004). Military Expenditure and Economic Growth: Peru 1970-1996. Journal of Defense and Peace Economics, 15, 275-287.

Knight, M., Loayaz, N. \& Villanueva, D. (1996). The Peace Dividend: Military Spending Cuts and Economic Growth. IMF Staff Papers, 43, 1-20.

Kollias, C. \& Makrydakis, S. (2000). A Note on the Causal Relationship between Defense Spending and Growth in Greece: 1955-93. Journal of Defense and Peace Economics, 11, 173-184.

Kollias, C., Naxakis, C. \& Zarangas, L. (2004). Defense Spending and Growth in Cyprus: A Causal Analysis. Journal of Defense and Peace Economics, 15, 299-307.

Levin, A., Lin, C. F. \& Chu, C. S. (2002). Unit Root Tests in Panel Data: Asymptotic and Finite Sample Properties, Journal of Econometrics, 108, 1-24.

Lim, D. (1983). Another Look at Growth and Defense in Less Developed Countries. Economic Development and Cultural Change, 31, 106-138.

Looney, R. E. (1986). The Political Economy of Latin American Defense Expenditures: case Studies of Venezuela and Argentina, Lexington, MA: Lexington Books.

Looney, R. E. \& Frederiksen, P. C. (1986). Defense Expenditures, External Public Debt and Growth in the Developing Countries. Journal of Peace Research, 23, 329-337. 
Melman, S. (1988). Economic Consequences of the Arms Race: The Second Rate Economy. American Economic Review, 78, 55-59.

Nadir, A. L. M. (1993). Economic Growth and Defense Spending in Sub-Saharan Africa: Benoit and Joerding Revisited. Journal of African Economies, 2, 146-156.

Ocal, N. (2003). Are the Military Expenditures of India and Pakistan External determinants of Each other: An Empirical Investigation? Defence and Peace Economics, 14, 141-149.

Pedroni, P. (2004). Panel Cointegration: Asymptotic and Finite Sample Properties of Pooled Time Series Tests with an Application to the PPP Hypothesis: New Results, Econometric Theory, 20, 597-627.

Phillips, P. C. B. \& Perron, P. (1988). Testing for a Unit Root in Time Series Regression, Biometrica, 75, 335-346.

Reitschuler, G. \& Loening, J. L. (2005). Modeling the Defence-Growth Nexus in Guatemala. World development, $33,513-526$.

Shieh, J. Y., Lai, C. C. \& Chang, W. Y. (2002). Endogenous Growth and Defence Expenditures: A New Explanation of the Benoit Hypothesis. Defence and Peace Economics, 13, 179-186.

Stroup, M. D. \& Heckelman, J. C. (2001). Size of the Military Sector and Economic Growth: A Panel Data Analysis of Africa and Latin America. Journal of Applied Economics, 4, 329-360.

Yildirim, J., Sezgin, S. \& Ocal, N. (2005). Military Expenditure and Economic Growth in Middle Eastern Countries: A Dynamic Panel Data Analysis. Defence and Peace Economics, 16, 283-295

Yildirim, J. \& Ocal, N. (2006). Arms race and Economic growth: The Case of India and Pakistan. Defence and Peace Economics, 17, 37-45.

Table 1. Univriate Unit Root Test Results

\begin{tabular}{|c|c|c|c|c|c|}
\hline Variables & India & China & Pakistan & Nepal & Conclusion \\
\hline GED & $\begin{array}{l}-2.03 \\
{[0.27]}\end{array}$ & $\begin{array}{l}-1.49 \\
{[0.79]}\end{array}$ & $\begin{array}{c}0.36 \\
{[0.98]}\end{array}$ & $\begin{array}{l}-0.196 \\
{[0.92]}\end{array}$ & 1 (1) \\
\hline GDP & $\begin{array}{c}2.71 \\
{[0.99]}\end{array}$ & $\begin{array}{c}0.85 \\
{[0.99]}\end{array}$ & $\begin{array}{c}1.65 \\
{[0.99]}\end{array}$ & $\begin{array}{c}-0.33 \\
{[0.98]}\end{array}$ & $1(1)$ \\
\hline PUD & $\begin{array}{l}-1.30 \\
{[0.60]}\end{array}$ & $\begin{array}{l}-1.00 \\
{[0.23]}\end{array}$ & $\begin{array}{c}0.49 \\
{[0.98]}\end{array}$ & $\begin{array}{l}-1.85 \\
{[0.35]}\end{array}$ & $1(1)$ \\
\hline$\triangle$ GED & $\begin{array}{l}-2.75 \\
{[0.08]}\end{array}$ & $\begin{array}{l}-3.15 \\
{[0.04]}\end{array}$ & $\begin{array}{c}-4.26 \\
{[0.00]}\end{array}$ & $\begin{array}{l}-3.04 \\
{[0.05]}\end{array}$ & $1(0)$ \\
\hline$\Delta$ GDP & $\begin{array}{l}-2.65 \\
{[0.10]}\end{array}$ & $\begin{array}{l}-2.61 \\
{[0.10]}\end{array}$ & $\begin{array}{l}-3.52 \\
{[0.02]}\end{array}$ & $\begin{array}{l}-3.75 \\
{[0.01]}\end{array}$ & I $(0)$ \\
\hline$\Delta \mathbf{P U D}$ & $\begin{array}{l}-4.52 \\
{[0.00]}\end{array}$ & $\begin{array}{l}-4.59 \\
{[0.00]}\end{array}$ & $\begin{array}{l}-3.19 \\
{[0.04]}\end{array}$ & $\begin{array}{l}-3.05 \\
{[0.05]}\end{array}$ & $\mathrm{I}(0)$ \\
\hline
\end{tabular}

Note: GED: Government Expenditure on Defense; GDP: Economic Growth; PUD: Public Debt; $\Delta$ : First difference operator; and the parenthesis indicate the probability of significance.

Table 2. Panel Unit Root Test Results

\begin{tabular}{|c|c|c|c|c|c|}
\hline Variables & IPS & LLC & ADF & PP & Conclusion \\
\hline GED & $\begin{array}{c}0.26 \\
{[0.60]}\end{array}$ & $\begin{array}{c}-0.83 \\
{[0.20]}\end{array}$ & $\begin{array}{l}8.645 \\
{[0.19]}\end{array}$ & $\begin{array}{c}5.15 \\
{[0.52]}\end{array}$ & $1(1)$ \\
\hline GDP & $\begin{array}{l}5.783 \\
{[0.99]}\end{array}$ & $\begin{array}{c}3.02 \\
{[0.99]}\end{array}$ & $\begin{array}{c}0.04 \\
{[0.99]}\end{array}$ & $\begin{array}{c}0.02 \\
{[0.99]}\end{array}$ & $1(1)$ \\
\hline PUD & $\begin{array}{c}1.396 \\
{[0.92]}\end{array}$ & $\begin{array}{l}1.496 \\
{[0.93]}\end{array}$ & $\begin{array}{c}2.35 \\
{[0.97]}\end{array}$ & $\begin{array}{c}3.79 \\
{[0.88]}\end{array}$ & $1(1)$ \\
\hline$\triangle$ GED & $\begin{array}{l}-1.97 \\
{[0.02]}\end{array}$ & $\begin{array}{c}-2.21 \\
{[0.00]}\end{array}$ & $\begin{array}{l}16.69 \\
{[0.03]}\end{array}$ & $\begin{array}{l}28.15 \\
{[0.00]}\end{array}$ & $\mathrm{I}(0)$ \\
\hline$\Delta$ GDP & $\begin{array}{l}-1.946 \\
{[0.02]}\end{array}$ & $\begin{array}{l}-2.809 \\
{[0.00]}\end{array}$ & $\begin{array}{l}16.12 \\
{[0.04]}\end{array}$ & $\begin{array}{l}24.06 \\
{[0.00]}\end{array}$ & $\mathrm{I}(0)$ \\
\hline$\Delta \mathbf{P U D}$ & $\begin{array}{l}-2.596 \\
{[0.00]}\end{array}$ & $\begin{array}{c}-3.17 \\
{[0.00]}\end{array}$ & $\begin{array}{l}20.59 \\
{[0.01]}\end{array}$ & $\begin{array}{l}36.76 \\
{[0.00]}\end{array}$ & $\mathrm{I}(0)$ \\
\hline
\end{tabular}

Note: IPS: IM, Pesaran and Shin W-stat; LLC: Levin, Lin \& Chu t-stat; ADF: ADF- Fisher Chi-square; PP: PP- Fisher Chi-square; and the parenthesis indicate the probability of significance. 
Table 3. Results of Johansen's Cointegration Test

\begin{tabular}{clllll}
\hline Countries & Null Hypothesis & \multicolumn{2}{c}{ Trace Statistics } & \multicolumn{2}{c}{ MEV Statistics } \\
\hline \hline \multirow{3}{*}{ China } & None & 50.95 & {$[0.00]$} & 27.12 & {$[0.00]$} \\
& At most 1 & 23.82 & {$[0.00]$} & 27.75 & {$[0.00]$} \\
& At most 2 & 1.07 & {$[0.30]$} & 1.07 & {$[0.30]$} \\
India & None & 25.19 & {$[0.04]$} & 17.50 & {$[0.05]$} \\
& At most 1 & 7.62 & {$[0.27]$} & 6.783 & {$[0.27]$} \\
& At most 2 & 0.84 & {$[0.41]$} & 0.84 & {$[0.41]$} \\
Nepal & None & 32.77 & {$[0.00]$} & 17.08 & {$[0.06]$} \\
& At most 1 & 15.68 & {$[0.01]$} & 13.37 & {$[0.02]$} \\
& At most 2 & 2.31 & {$[0.15]$} & 02.31 & {$[0.15]$} \\
Pakistan & None & 34.98 & {$[0.01]$} & 21.2 & {$[0.05]$} \\
& At most 1 & 13.78 & {$[0.09]$} & 8.68 & {$[0.03]$} \\
& At most 2 & 5.09 & {$[0.02]$} & 5.09 & {$[0.02]$} \\
\hline \hline$=$
\end{tabular}

Note: *: Indicates probability of significance at $1 \%$; **: Indicates probability of significance at $10 \%$.

Table 4. Panel Cointegration Tests

\begin{tabular}{|c|c|c|c|c|c|}
\hline Residual & Cointegration & Test & Fischer $\chi^{2}$ & Cointegration & Test \\
\hline Panel v-statistic & $14.93^{*}$ & & $r=0$ & $\mathrm{r} \leq 1$ & $r \leq 2$ \\
\hline Panel $\rho$ - statistic & 2.283 & $\lambda_{\text {Tra }}:$ & 37.47 & 22.04 & 19.56 \\
\hline Panel PP- statistic & 3.627 & $\lambda_{\text {Max }}:$ & 23.48 & 17.14 & 19.56 \\
\hline Panel ADF- statistic & 1.921 & & & & \\
\hline Group $\rho$ - statistic & 2.356 & & & & \\
\hline Group PP-statistic & 2.735 & & & & \\
\hline Group ADF- statistic & 1.901 & & & & \\
\hline
\end{tabular}

Note: *: Indicates probability of significance.

Table 5. Granger Causality Test based on ECM

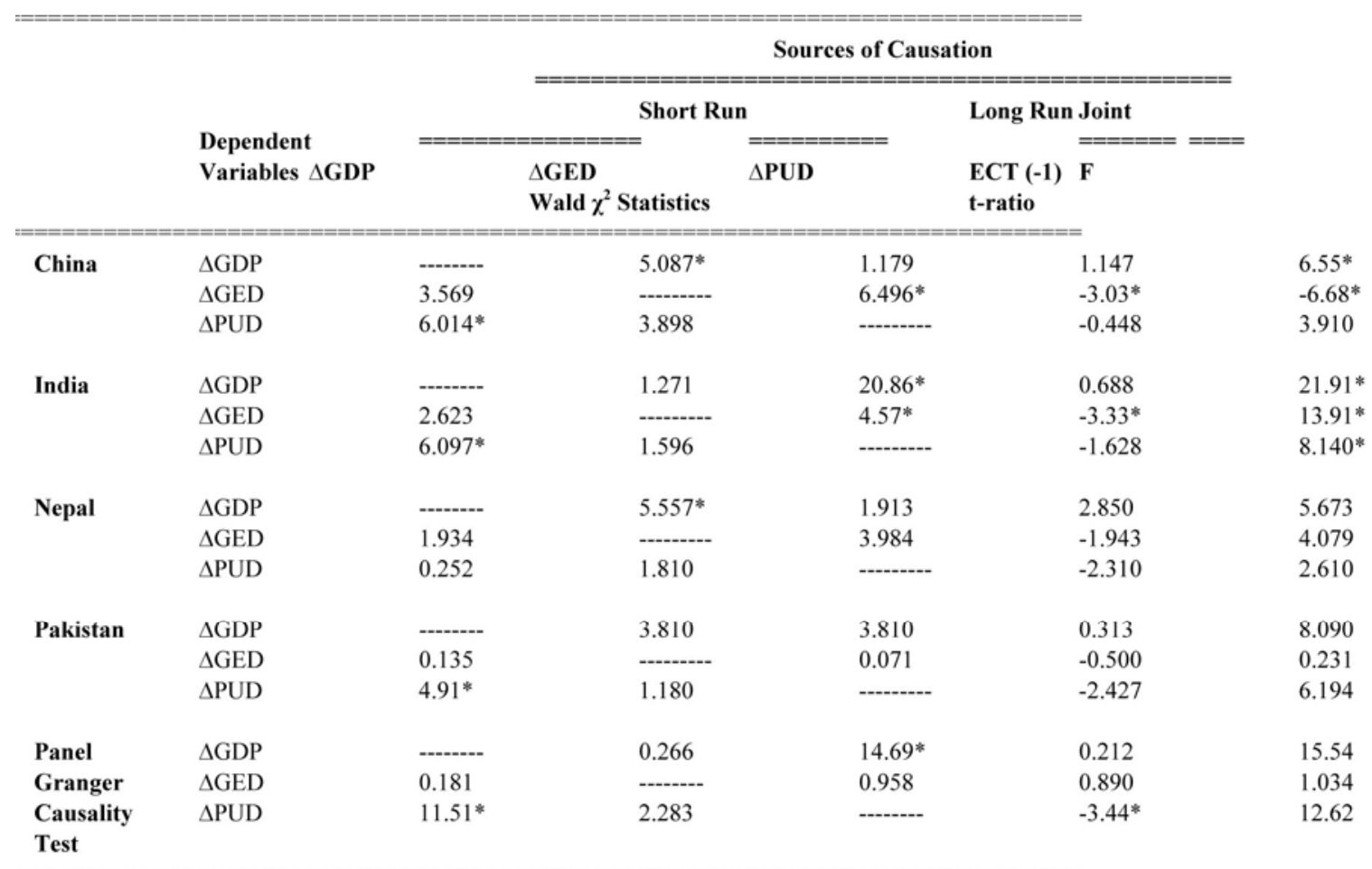

Note: $*$ : Indicates statistically significant at $1 \%$. 
Table 6. Results of Johansen's Cointegration Test

\begin{tabular}{|c|c|c|c|c|}
\hline \multirow{2}{*}{$\begin{array}{l}\text { Between Countries } \\
\text { India and Pakistan }\end{array}$} & Null Hypothesis & Trace Statistics & \multicolumn{2}{|c|}{ MEV Statistics } \\
\hline & None & {$[0.19]$} & 12.67 & {$[0.35]$} \\
\hline & At most 1 & {$[0.24]$} & 8.08 & {$[0.25]$} \\
\hline \multirow[t]{2}{*}{ India and China } & None & {$[0.17]$} & 10.26 & {$[0.31]$} \\
\hline & At most 1 & {$[0.21]$} & 5.73 & {$[0.21]$} \\
\hline \multirow{2}{*}{ India and Nepal } & None & {$[0.14]$} & 12.21 & {$[0.10]$} \\
\hline & At most 1 & {$[0.70]$} & 0.148 & {$[0.70]$} \\
\hline \multirow[t]{2}{*}{ Pakistan and China } & None & {$[0.31]$} & 8.81 & {$[0.29]$} \\
\hline & At most 1 & {$[0.40]$} & 0.705 & {$[0.40]$} \\
\hline \multirow[t]{2}{*}{ Pakistan and Nepal } & None & {$[0.37]$} & 6.33 & {$[0.31]$} \\
\hline & At most 1 & {$[0.66]$} & 0.27 & {$[0.66]$} \\
\hline \multirow[t]{2}{*}{ China and Nepal } & None & [0.59] & 6.78 & {$[0.52]$} \\
\hline & At most 1 & {$[0.69]$} & 0.152 & {$[0.69]$} \\
\hline India, Pakistan & None & {$[0.07]$} & 20.4 & {$[0.06]$} \\
\hline \multirow[t]{2}{*}{ and China } & At most 1 & {$[0.47]$} & 7.97 & {$[0.39]$} \\
\hline & At most 2 & {$[0.81]$} & 0.061 & {$[0.81]$} \\
\hline India, Nepal & None & {$[0.46]$} & 10.48 & {$[0.44]$} \\
\hline \multirow[t]{2}{*}{ and China } & At most 1 & {$[0.64]$} & 3.23 & {$[0.75]$} \\
\hline & At most 2 & {$[0.30]$} & 1.28 & {$[0.30]$} \\
\hline Nepal, Pakistan & None & {$[0.22]$} & 11.78 & {$[0.32]$} \\
\hline \multirow[t]{2}{*}{ and China } & At most 1 & {$[0.34]$} & 6.79 & {$[0.27]$} \\
\hline & At most 2 & {$[0.88]$} & 0.035 & {$[0.88]$} \\
\hline India, Pakistan & None & {$[0.60]$} & 23.83 & {$[0.02]$} \\
\hline \multirow[t]{2}{*}{ and Nepal } & At most 1 & {$[0.05]$} & 13.83 & {$[0.06]$} \\
\hline & At most 2 & {$[0.16]$} & 1.966 & {$[0.16]$} \\
\hline India, Pakistan, & None & {$[0.00]^{*}$} & 28.17 & {$[0.04]^{*}$} \\
\hline \multirow[t]{3}{*}{ Nepal and China } & At most 1 & {$[0.01]^{*}$} & 23.99 & {$[0.01]^{*}$} \\
\hline & At most 2 & {$[0.15]$} & 10.32 & {$[0.19]$} \\
\hline & At most 3 & {$[0.18]$} & 1.823 & {$[0.18]$} \\
\hline
\end{tabular}

Note: *: Indicates probability of significance at $1 \%$

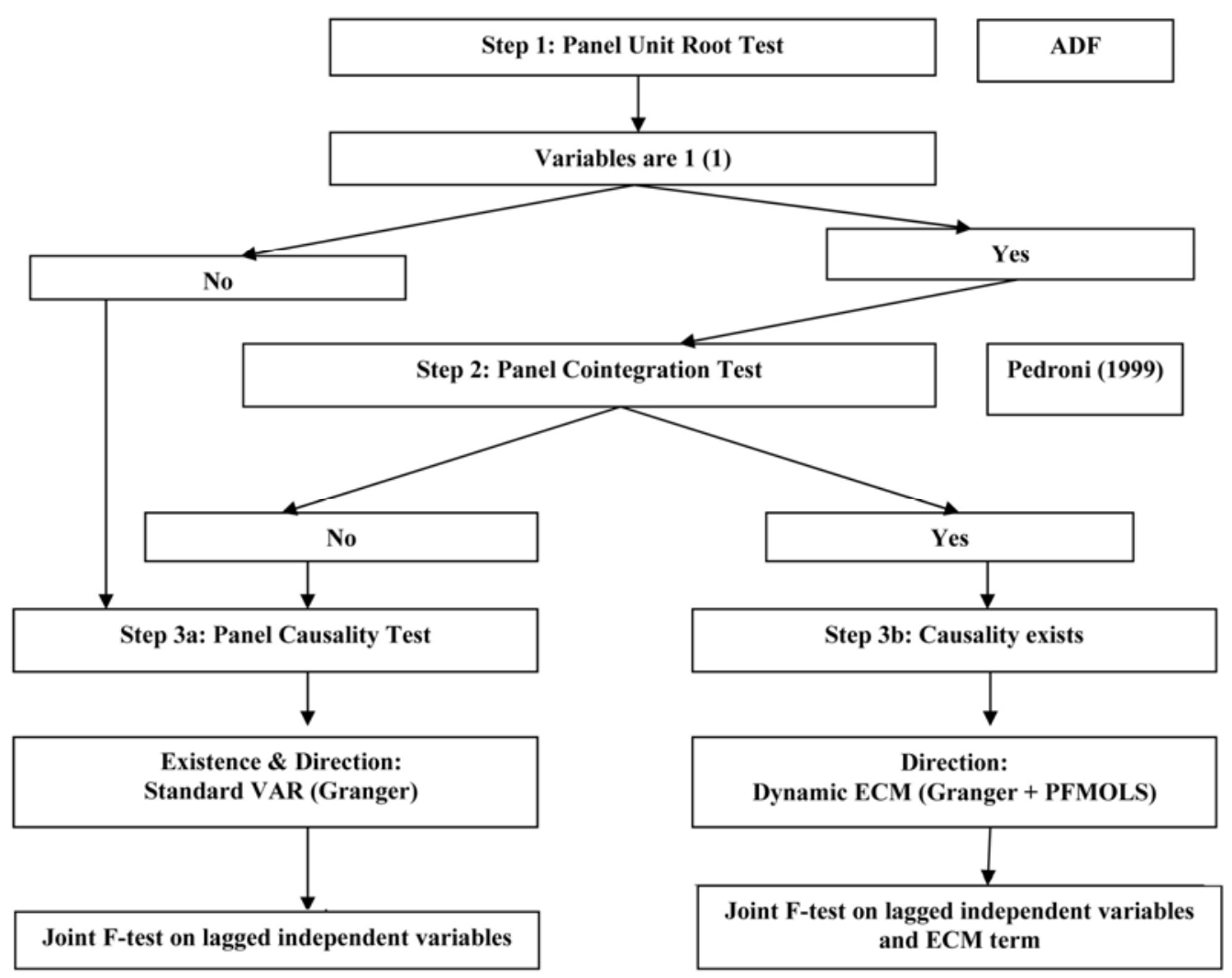

Figure 1. Panel Causality Testing Framework 